\title{
Redescription of Terebellides kerguelensis stat. nov. (Polychaeta: Trichobranchidae) from Antarctic and subantarctic waters
}

\author{
Julio Parapar · Juan Moreira
}

Received: 20 February 2007 / Revised: 13 September 2007 / Accepted: 24 September 2007 / Published online: 24 October 2007

(C) Springer-Verlag and AWI 2007

\begin{abstract}
During the Spanish Antarctic expeditions "Bentart" 1994, 1995 and 2003, a number of trichobranchid (Annelida: Polychaeta) specimens were collected and identified initially as Terebellides stroemii kerguelensis McIntosh, 1885 , the only known species of the genus widely recognised as valid in Antarctic waters. In the framework of a worldwide revision of the genus Terebellides, a reconsideration of the taxonomic status of this subspecies of the boreal Terebellides stroemii Sars, 1835 is done through the examination of the syntypes of $T$. s. kerguelensis compared with recent descriptions of the nominal species from Norwegian waters and material from Icelandic waters. Thus, T. s. kerguelensis is regarded as a valid species, T. kerguelensis stat. nov., and redescribed designating a lectotype and paralectotypes. The species is mainly characterised by the presence of an anterior branchial extension (fifth lobe), lateral lappets in five anterior thoracic chaetigers, segmental organs in chaeti-
\end{abstract}

Communicated by Peter Funch.

J. Parapar $(\bowtie)$

Departamento de Bioloxía Animal, Bioloxía Vexetal e Ecoloxía, Facultade de Ciencias, Universidade da Coruña, Rúa Alejandro da Sota 1, 15008 A Coruña, Spain e-mail: jparapar@udc.es

J. Moreira

Estación de Bioloxía Mariña da Graña, Universidade de Santiago de Compostela,

Rúa da Ribeira 1, A Graña, 15590 Ferrol, Spain

J. Moreira

Departamento de Bioloxía Animal e Instituto de Acuicultura, Universidade de Santiago de Compostela,

Campus Sur, 15782 Santiago de Compostela, Spain gers 1, 4 and 5, and first thoracic acicular neurochaetae sharply bent with pointed tips. The biological role of the segmental organs, the presence and disposition of cilia in branchial lamellae and the finding of new structures located in dorsal part of thoracic notopodia are discussed.

Keywords Annelida Terebellides stroemii kerguelensis · Bentart project · Antarctic peninsula · Kerguelen Island $\cdot$ Antarctica $\cdot$ New status

\section{Introduction}

The genus Terebellides was established by Sars (1835) for Terebellides stroemii from material collected off the coast of Norway. Since then, the species has been reported from distant geographic areas, which led to a cosmopolitan consideration of the taxon: e.g. Europe (Fauvel 1927), South Africa (Day 1967), Australia (Hutchings 1977) and Gulf of Mexico (Kritzler 1984). Holthe (1986a) in his monograph on Scandinavian Terebellomorpha, reported worldwide records of this species from literature whilst recognizing that most of them might probably belong to undescribed species morphologically and phylogenetically close. Williams (1984), after revising material identified as T. stroemi from different geographic areas, rejected the cosmopolitan status of this species, described four new species and proposed new characters useful for distinguishing species/subspecies. Williams did not, however, examine material from Antarctica. After Williams' revision, new species of Terebellides were described from elsewhere. Thus, Imajima and Williams (1985) reported six species of Terebellides from two bays in Japan, three of them new to science, revealing this way an unexpectedly great diversity of this genus in such a small geographic area. Solis-Weiss et al. (1991) 
described three new species from shallow tropical waters in the western Atlantic Ocean, Bremec and Elias (1999) described two species from off Argentina, and Hilbig (2000) reported from Californian waters three species previously described by Williams (1984) and Imajima and Williams (1985) and further described two new species. Simultaneously, Hutchings and Peart (2000), in a revision of the Trichobranchidae from Australia, redescribed $T$. stroemi from material collected at Porsangerfjord (Norway) near the type locality, described four new species from Australian waters and propose additional characters to facilitate species differentiation. Recently, Garraffoni and Lana (2003) described a new species from Brazil and provide a useful key for most of the known species of Terebellides. Garraffoni and Lana (2004) presented a cladistic analysis of trichobranchids, summarizing the current knowledge on systematics of the group and revising the interpretation of some morphological characters, and Garroffoni et al. (2005) compiled a complete catalogue of world Trichobranchinae.

Since the original description, the specific epithet has been written in five different ways (see Garraffoni et al. 2005); in this work we adopt stroemii, the most widely used today.

The taxonomic history of the genus Terebellides in the Southern Ocean started in the late nineteenth century, when McIntosh (1885) described Terebellides stroemi kerguelensis from specimens collected in January 1874 off the subantarctic Kerguelen Island during the voyage of HMS Challenger, and Ehlers $(1897,1901)$ reported the stem species from the Magellanic region. In the twentieth century, Hessle (1917) published a worldwide revision of terebelliform polychaetes, describing three new species from the Antarctic and southern South American waters: Terebellides antarcticus from shallow waters off Graham's Land, Terebellides minutus from Patagonia and Terebellides longicaudatus from South Georgia. Later, Monro (1930) considered T. antarcticus and T. minutus as synonyms of $T$. $s$. kerguelensis. Hartman (1953), however, referred to the presence of T. antarcticus, T. longicaudatus and T. minutus from Tierra del Fuego, South Georgia and the Palmer archipelago, but soon after, in her catalogue of world polychaetes (Hartman 1959) she used Monro's synonymies. This is eventually reflected in her compilation on Antarctic "sedentary" polychaetes (Hartman 1966, p. 113, pl. 38, Figs. 4-7) in which she also recorded the presence in Antarctic waters of T. stroemii by including previous authors' citations (e.g. Ehlers 1897; Augener 1932).

In his catalogue of world Terebellomorpha, Holthe (1986b) only recognized T. s. kerguelensis and T. longicaudatus as valid subespecies and species in Antarctic and subantarctic waters, including T. antarcticus and T. minutus as synonyms of the former.
Subsequent to Hartman (1966), and with the exception of Cantone and Di Pietro (2001) who recorded again the nominal species, later works in Antarctic and subantarctic waters reported $T$. s. kerguelensis as the only species of this genus in the area (e.g. Levenstein 1966, p. 185; Hartman 1967, p. 172; 1978, p. 202; Hartmann-Schröder and Rosenfeldt 1989, p. 92; 1991 p. 88; Parapar and San Martín 1997, p. 507, Fig. 1 C-F; San Martín et al. 2000, p. 94; Sicinski and Gillet 2002, p. 354; Sicinski 2004, p. 81). Thus, the known distribution of T. s. kerguelensis was confined to Magellanic and Antarctic waters and such subantarctic islands as Kerguelen and South Georgia (Rozbaczylo 1985; Bremec and Elias 1999; Rozbaczylo et al. 2006).

In the present study, McIntosh's type material of $T$. $s$. kerguelensis from Kerguelen Island is revised and redescribed. The material identified as T. s. kerguelensis from the Spanish "Bentart" cruises $(1994,1995,2003)$ in the South Shetlands islands and Bellingshausen Sea (Antarctica) is used to complement the description. Specimens identified as Terebellides $\mathrm{cf}$. stroemii from northern Icelandic waters were also used for comparison purposes. As a result of this examination, Antarctic material of T. s. kerguelensis it is proposed to change its status to that of a separate species.

\section{Methods}

Type material of T. s. kerguelensis was loaned by the Natural History Museum (NHM, London). The material consists of two vials: (1) Vial 380: Station (Stn.) 149G, off London River, Kerguelen, January 29 1874, latitude $48^{\circ} 50^{\prime}$ S, longitude $69^{\circ} 18^{\prime} \mathrm{E}, 110$ fathoms, and (2) Vial 381: Stn. 149H, off Cumberland Bay, January 29 1874, 127 fathoms. No holotype or paratypes were initially designated by the author in the original description and none of these specimens could be positively identified from drawings as only chaetae were originally illustrated (see McIntosh 1885, p. 480 and plates XXIXA and XXXVIIIA). The specimen selected by McIntosh for the original description was probably one of the two specimens separated from the other two in a small tube in vial 380. One of these specimens has scars on the neuropodia of chaetigers 8,9 and 10 which suggests that chaetae from this specimen were probably used for his drawings (Fig. 1b). Following ICZN art. 74, one of the syntypes from Stn. 149G (vial 380) was designated as a lectotype and the other specimens as paralectotypes. In this case, however, the specimen selected as the lectotype was not that with the scars on the neuropodia of chaetigers 8,9 and 10 but the other specimen in the small vial which is in better condition (Fig. 1a).

Specimens belonging to the Bentart project were obtained during 1994, 1995 and 2003 cruises. Information 
Fig. 1 Terebellides kerguelensis McIntosh, 1885 stat. nov. a-c Anterior end in lateral view of McIntosh's syntypes selected as lectotype (a) and paralectotypes (b-d), BMNH 1885.12.1.380. Segments numbered $\mathrm{S} 1$ to $\mathrm{S} 3$; $\mathrm{tm}$ tentacular membrane; $p p$ papillar projection; branchial lobes numbered $i$ to iv
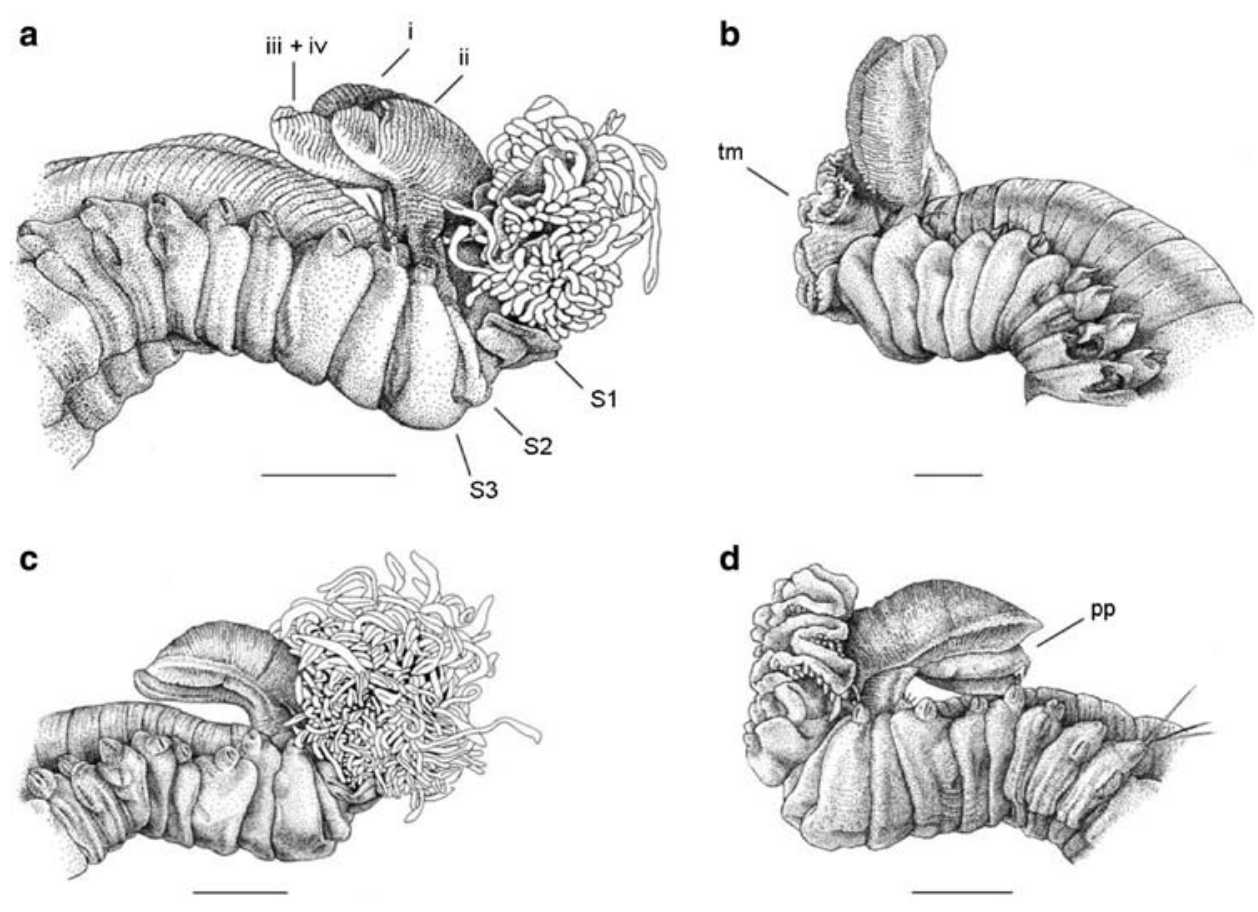

concerning Polychaeta from 1994 and 1995 surveys in the South Shetland islands and Antarctic peninsula can be found in San Martín and Parapar (1997), Parapar and San Martín (1997) and San Martín et al. (2000). Material collected during 2003 in the Bellingshausen Sea is still being studied.

Specimens were fixed in $10 \%$ buffered formalin and preserved in $70 \%$ ethanol. Observations, drawings and measurements were made using an Olympus SZX9 stereomicroscope and an Olympus BX40 compound microscope, both provided with drawing tubes. The "Bentart" specimens used to complement the description of the new species were deposited at the Museo Nacional de Ciencias Naturales (MNCN, Madrid), in the NHM, London and in the personal collection of the first author in the Departamento de Bioloxía Animal (Universidade da Coruña).

Specimens used for scanning electron microscopy (SEM) were dehydrated via a graded ethanol series, critical-point dried using $\mathrm{CO}_{2}$, covered with gold in a BALTEC SCD 004 sputter coater at the SAIN (Universidade da Coruña, Spain), and examined and photographed under a LEICA LEOS 435VP SEM at the RIAIDT (Universidade de Santiago de Compostela, Spain). The dental formula for composition of neurochaetal teeth and nomenclature of branchial lobes are those of Hutchings and Peart (2000).

Additional material of Terebellides cf. stroemii examined for comparison from the polychaete collection of the BIOICE project was loaned by the Icelandic Institute and Museum of Natural History (IMNH, Reykjavik). Information related to the BIOICE project can be found in Parapar (2003).

\section{Results}

Family Trichobranchidae Malmgren, 1866

Genus Terebellides Sars, 1835

Terebellides kerguelensis McIntosh, 1885 stat. nov.

Figs. 1, 2, 3, 4, 5

\section{Terebellides stroemi kerguelensis}

McIntosh 1885: 480, pl. XXIXA, Figs. 7, 8 and pl. XXXVIIIA, Fig. 4; Parapar and San Martín 1997: 507, Fig. 1CF; San Martín et al. 2000: 94.

Type material

NHM 1885.12.1.380 (4 syntypes from Stn. 149G, off London River, Kerguelen Island); NHH 1885.12.1.381 (2 syntypes from Christmas Harbour, Kerguelen Island).

Non-type material

MNCN, "Bentart" 1995 cruise, Livingston Island (South Shetland Islands, Antarctica), Stn. 6 (January 18 1995, $62^{\circ} 43,8170^{\prime} \mathrm{E}, 60^{\circ} 26,2575^{\prime} \mathrm{S}, 66 \mathrm{~m}, 3$ specimens, MNCN 16.01/6609), Stn. 7 (January 18 1995, 6244,2918'E, $60^{\circ} 28,1958^{\prime} \mathrm{S}, 80 \mathrm{~m}, 9$ spec., MNCN 16.01/6610) Natural History Museum (NHM, London): "Bentart" 1995 cruise, Livingston Island (South Shetland Islands), Stn. 4 (January $171995,62^{\circ} 38,6188^{\prime} \mathrm{E}, 60^{\circ} 25,1776^{\prime} \mathrm{S}, 94 \mathrm{~m}, 2$ spec., NHM 2007.786-787); "Bentart” 2003 cruise, Paraíso Bay, 
Fig. 2 Terebellides kerguelensis McIntosh, 1885 stat. nov. SEM micrographs of specimen from "Bentart-1994" cruise (Stn 1). a Anterior end, ventrolateral view (segments numbered). b Notopodium and nephridial papilla of first thoracic chaetiger. c Second thoracic chaetiger, dorsal view. d Detail of "thoracic papilla" from second thoracic chaetiger. e Thoracic chaetigers 4 and 5, dorsal view. f Thoracic chaetigers 6 to 8 , lateral view. Gs sixth chaetiger geniculate neurochaetae, $l l$ lateral lappet; thp thoracic papilla; npo nephridial pore; $\mathrm{tm}$ tentacular membrane
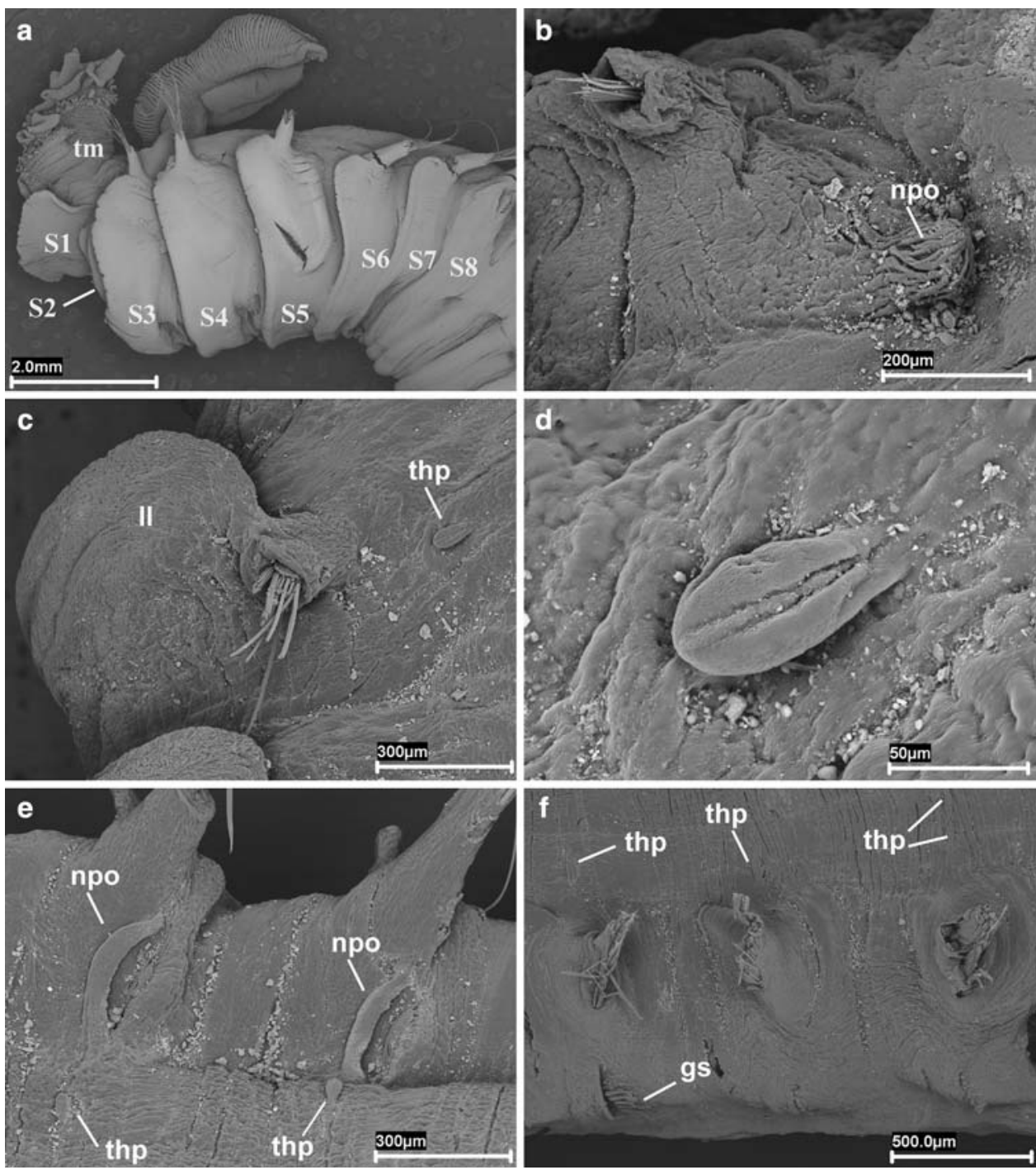

Bransfield Strait, Stn. 21 (23 February 2003, 64 $54^{\circ} 04^{\prime \prime} E$, $63^{\circ} 00^{\prime} 52^{\prime \prime} \mathrm{S}, 94 \mathrm{~m}, 1 \mathrm{spec}$, NHM 2007.788).

Other material examined

Terebellides cf. stroemii from BIOICE project around Iceland. Station 2065 (17 spec.), Stn. 2082 (3 spec.), Stn. 2152 (37 spec.), Stn. 2317 (22 spec.).

Type locality

Off London River and Christmas Harbour, north Kerguelen Island, subantarctic Indian Ocean.

Description based on the designated lectotype

Complete specimen of $21 \mathrm{~mm}$ in length and $2 \mathrm{~mm}$ in width (Fig. 1a); body tapering posteriorly with segments increasingly shorter and crowded towards pygidium. Prostomium compact; tentacular membrane surrounding the mouth and provided with two types of buccal tentacle: uniformly tapered and with expanded tips, respectively (Fig. 1a, c). First segment forming an expanded structure ("lower lip" sensu Hutchings and Peart 2000) below tentacular membrane (Figs. 1a, 2a, 3a). Eyespots absent. Branchiae arising as a single structure from segments $3-4$, consisting of a single mid-dorsal stalked structure (Fig. 3a, b) made up of two pairs of similar-sized lobes; branchial lobes fused together for at least half of their length (i-iv sensu Hutchings and Peart 2000; Fig. 1a); an additional anterior projection also present (fifth lobe sensu Solis-Weiss et al. 1991 and Hutchings and Peart 2000). Posterior region of lobes each with a pointed projection (Fig. 1d). Both sides of branchial lamellae with several rows of cilia (Fig. 3d-e) each row fitting in between two rows of cilia on the opposite lamella (Fig. 3f). Lateral lappets on chaetigers 1-5 (segments 3-7; Figs. 1, 2a,c, 3a), anterior margins separated from body wall; a swollen glandular area in chaetigers 1-3 (Fig. 1). Rounded 
Fig. 3 Terebellides kerguelensis McIntosh, 1885 stat. nov. SEM micrographs of specimens from "Bentart-1994" cruise (Stn. 19) and "Bentart-1995" (Stn. 4). a Anterior end in lateral view showing compact prostomium over tentacular peristomial membrane. b Branchial double stalk arising from segments 3 and 4. c Tentacular membrane and branchiae with disordered lamellae. $\mathbf{d}$ Detail of cilia of branchial lamellae. e Branchial lamellae in 'parallel' position with rows of cilia 'face to face'. f Detail of branchial lamellae rows of cilia 'fitted' to each other. $\operatorname{Pr}$ prostomium; per peristomium; $t m$ tentacular membrane; bap branchial anterior projection
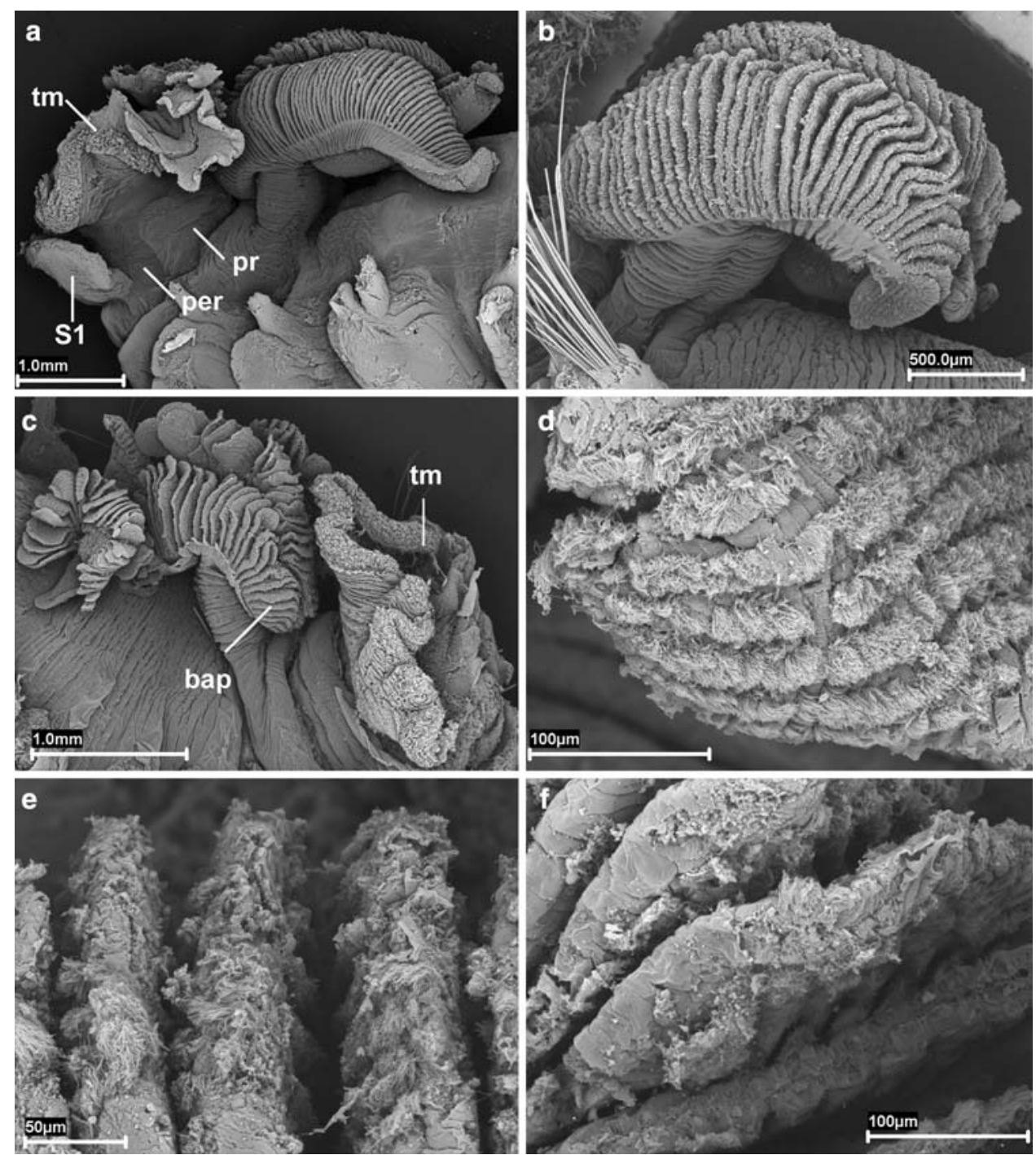

dorsal projections from chaetigers 1 to 5 , more conspicuous on chaetigers 4-5. Ventral glandular bands absent.

Eighteen pairs of notopodia (segments 3-20), compact, rectangular and of similar size. Neuropodia present from chaetiger 6 (segment 8) to pygidium. Thoracic neuropodia as sessile pinnules; abdominal neuropodia as erect pinnules. Notochaetae of first pair of notopodia similar in length and thickness to notochaetae of subsequent notopodia but less numerous (Fig. 2a). All notochaetae simple, broad-winged capillaries with textured surfaces (Fig. 4a-d). No accessory chaetae present.

Neuropodial uncini in single rows throughout. First thoracic neuropodia (chaetiger 6 ) with 5-8 sharply bent, acutetipped, geniculate acicular hooks (Fig. 4e-f). Second and all subsequent thoracic neuropodia with up to 20 uncini per torus. Uncini long-shafted denticulate hooks with main fang large and surmounted by $2-4$ big teeth and a crest of many denticles (Fig. 5a-b); dental formula MF:2-4: $\infty$. About 33 abdominal neuropodia; about 35 avicular uncini per torus with 3-4 teeth above main fang surmounted by 12 teeth and an upper crest of a variable number of smaller teeth (Fig. 5c-e); dental formula MF:3-4:1-2: $\infty$. No abdominal notopodia.

One large nephridial papilla on each notopodium of chaetiger 1 (segment 3), with the appearance of a long, distally truncate cone (Fig. 2b). Two shallow and wider buttonhole-like nephridial pores located in the basal part of notopodia of chaetigers 4 and 5 (segments 6 and 7; Fig. 2e). Small spherical papillae arising dorsally to notopodia in all thoracic chaetigers except chaetiger 1 ("thoracic papillae", Fig. 2c-f). Oocytes present in coelomic abdominal cavities (Fig. 5f). Pygidium blunt, with a funnel-like depression with crenulated edge.

Additional observations from non-type material

Larger specimens belonging to "Bentart" cruises (up to $45 \mathrm{~mm}$ in length and $4 \mathrm{~mm}$ in width) show a similar 
Fig. 4 Terebellides kerguelensis McIntosh, 1885 stat. nov. SEM micrographs of specimen from "Bentart-1994" cruise (Stn. 1). a Thoracic notopodium (chaetiger 8) and notochaetae. b-d Thoracic notochaetae (chaetiger 1), detail of covering scales. e-f Geniculate chaetae of chaetiger 6
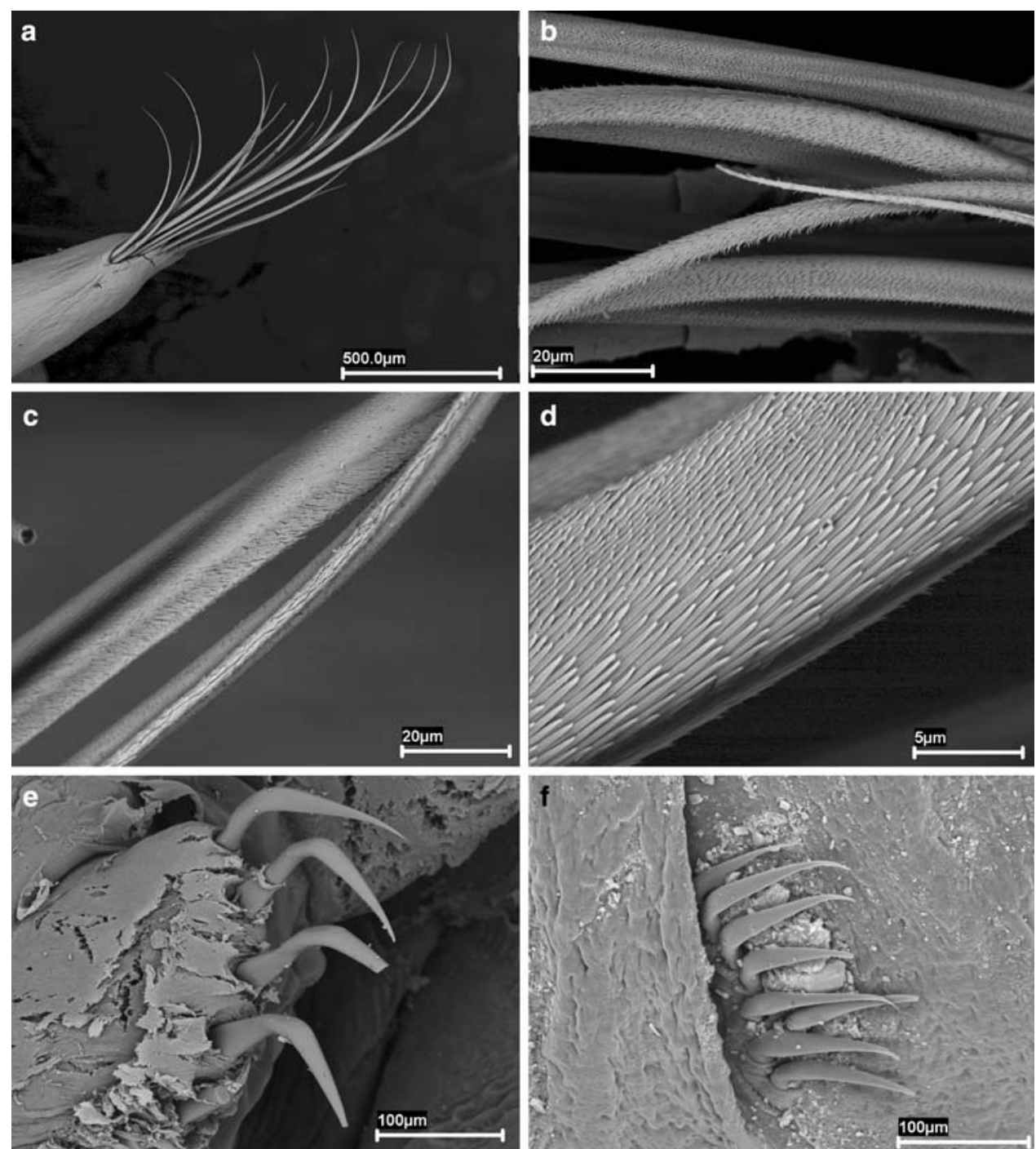

number of abdominal chaetigers (30-35) but with more uncini (up to 60). Some specimens have a greatly developed swollen glandular area of increasing size from chaetigers 1 to 3 , which could be related to sexual maturity. The buttonhole-like thoracic segmental pores in the dorsal part of chaetigers 4 and 5 are more apparent than in the type material even at low magnification.

\section{Ecological notes}

Type material was collected at depths of between 110 and 127 fathoms (about 201-232 m). Additional material from "Bentart" expeditions suggests that T. kerguelensis stat. nov. is a shallow-water shelf species (21-263 m depth). In contrast, no specimens of this species were collected on deeper bottoms from shelf and slope in the Bellinghausen Sea during "Bentart" cruises in 2003 and 2006. These cruises, however, yielded specimens from shallower waters off Peter I island and the Bransfield Strait (90-94 m).
This species has mainly been found in soft-bottoms ranging from mud to sandy mud. Oocytes of about $45 \mu \mathrm{m}$ in diameter.

Known distribution

Kerguelen island (subantarctic Indian Ocean) and South Shetland islands (Antarctic peninsula), Bransfield Strait and Peter I island (Bellingshausen Sea).

\section{Discussion}

Terebellides is the most diverse genus in the family Trichobranchidae Malmgren, 1866 and is comprised of species similar in appearance. Hartman (1959) synonymised with T. stroemii Sars, 1835 many of the species known so far, which, as affirmed by Hutchings and Peart (2000) contributed to the assumption that $T$. stroemii was a cosmopolitan 
Fig. 5 Terebellides kerguelensis McIntosh, 1885 stat. nov. SEM micrographs of a specimen from "Bentart-1994" cruise (Stn. 1): a Thoracic neuropodial uncini of chaetiger 9 in lateral view. b Thoracic neuropodial uncini of chaetiger 12 in upper view. c Abdominal posterior neuropodium and uncini. $\mathbf{d}$ Abdominal neuropodial uncini in frontal view. e Abdominal neuropodial uncini in lateral view. f Detail of oocytes
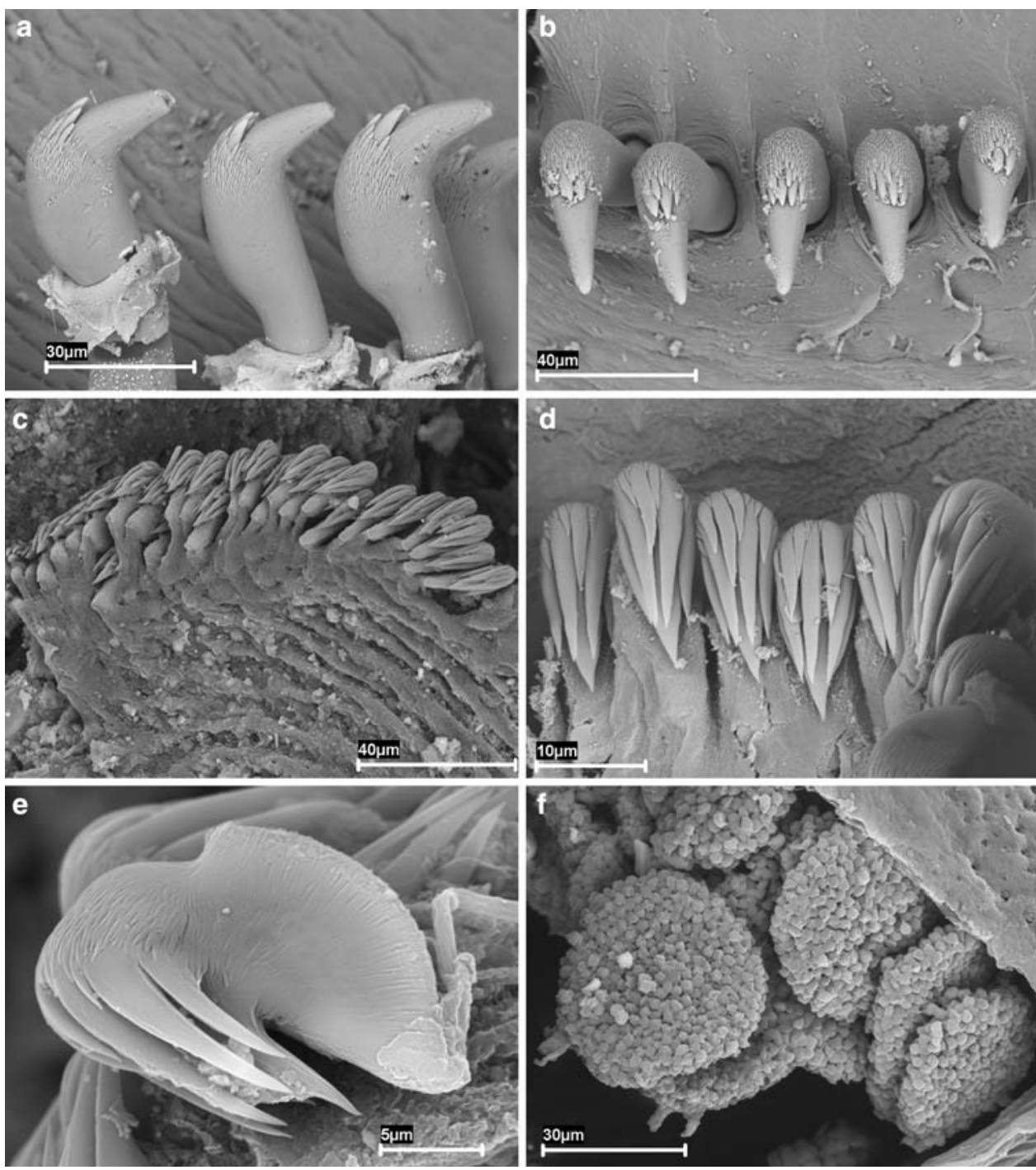

species and thus Terebellides specimens found elsewhere were identified as that species. In the last two decades, revision of material from different parts of the world demonstrated, however, that this consideration was wrong and a number of useful characters were proposed to separate species within the genus (Williams 1984; Imajima and Williams 1985; Holthe 1986a, b; Solis-Weiss et al. 1991; Hutchings and Peart 2000). The characters are: presence or absence of thoracic lateral lappets, number and relative development of branchial lobes, degree of development of notochaetae of first chaetiger, morphology of thoracic acicular chaetae, number of uncini of thoracic neuropodia, number of abdominal chaetigers and number and position of nephridial papillae.

Terebellides kerguelensis stat. nov. differs from the description of T. stroemii by Hutchings and Peart (2000) in the shape of the neuropodial spines of chaetiger 6 and the position of the segmental organs, as T. kerguelensis stat. nov. has acute-tipped geniculate hooks and small and rounded papillae in segments 3 and 4 instead of the smoothtipped hooks and papilla on segments 3, 6 and 7 of T. stroemii. The small size and differences observed in number and shape of branchiae (2-4 lobes loosely fused) of BIOICE specimens makes their identification as $T$. stroemii doubtful. The Australian species Terebellides narribri Hutchings and Peart, 2000 and Terebellides woolawa Hutchings and Peart, 2000 are related to T. kerguelensis stat. nov. in the number and degree of fusion of branchial lobes. Terebellides narribri is similar to T. kerguelensis stat. nov. in the shape of acicular neuropodia of chaetiger 6 and number, disposition and shape of nephridial papillae; the two species differ in the presence of two types of notochaetae and the absence of dorsal projections in thoracic lateral lappets in T. narribri. Terebellides woolawa is close to T. kerguelensis stat. nov. because of the presence of only one type of notochaetae and big lateral lappets in segments 3-7 (chaetigers 1-5) which also gradually become smaller backwards and have rounded projections. Nevertheless, 
T. woolawa differs from T. kerguelensis stat. nov. in the smaller size of the first two pairs of thoracic notopodia which are also located more dorsally, in the presence of only one pair of nephridial papillae on segment 3 and in lacking buttonhole-like papillae in chaetigers 4 and 5 .

The Brazilian species Terebellides lanai Solis-Weiss et al., 1991 and the Argentinian Terebellides totae Bremec and Elias, 1999 are also very similar to T. kerguelensis stat. nov. T. lanai differs in having shorter and a smaller number of notochaetae in the first chaetiger and in the smaller number of abdominal chaetigers (25-29 vs. 30-35) and T. totae differs in having the first chaetiger reduced with few notochaetae and the anterior dorsum smoothly curved up to chaetiger 7 .

Among the species described by Imajima and Williams (1985) from Japanese waters, Terebellides kobei Imajima and Williams, 1985 is very similar to T. kerguelensis stat. nov. in the shape of thoracic lateral lappets, acicular chaetae, thoracic uncini and in having a swollen glandular area on chaetiger 3 , but differs from $T$. kerguelensis stat. nov. in the larger size of the first thoracic notochaetae on chaetiger 1 (segment 3). Unfortunately, no information on nephridial pores is provided in the original description.

Hartmann-Schröder (1965) described Terebellides bisetosa from the Chilean coast. This species, recently reported by Montiel et al. (2004) from fjords and channels adjacent to the southern Patagonian ice-shelf in Chile, is related to $T$. kerguelensis stat. nov. in the length of thoracic notochaetae, acicular neurochaetae from chaetiger 6 and presence of an anterior expansion on branchial lobes (fifth lobe). Both species differ, however, in the presence in $T$. bisetosa of two types of notochaetae from chaetiger 8: long and short capillaries, the latter with the appearance of a hooded paintbrush. In addition, there is a smaller degree of fusion of branchial lobes in T. bisetosa.

Terebellides antarcticus, T. longicaudatus and T. minutus described by Hessle (1917) from Antarctic and Patagonian waters are traditionally considered junior synonyms of T. s. kerguelensis. As a study of type material lodged in the Stockholm Museum of Natural History (Sweden) is currently being undertaken by the author's revision of the status of these species might reveal the actual diversity of the genus in the southern ocean.

The study of the order Terebellomorpha-sensu Dales (1962)_represents one of the few cases in Polychaeta where internal anatomy has been used for classification (e.g. Hessle 1917 in Rouse 2001). Although most taxonomic works on this group have disregarded internal characters, the number, position and shape of nephridial openings in the thoracic region is still used as a relevant character to distinguish species within Trichobranchidae (e.g. Solis-Weiss et al. 1991; Hutchings and Peart 2000). The genus Terebellides usually has a single pair of segmental organs anterior to the gular membrane (the muscular septum between the two anterior segments) with excretory function. In addition a number of posterior pairs are also present for gamete release (Hessle 1917; Goodrich 1945 and Bartholomaeus 1999 in Rouse and Fauchald 1997). The latter occur in segments which often lack complete septa allowing interconnection of segmental coelomic cavities (Rouse and Pleijel 2001). In T. kerguelensis stat. nov., the differences in opening shape of segmental organs might also reflect these different biological roles. Thus, organs from chaetiger 1 are truncated cones and those from chaetigers 4-5 have a buttonhole-like shape. The larger size of the latter (about $300 \mu \mathrm{m}$ width) seems to be a modification for gamete release and their enlarged shape might also reflect a state of maturity similarly to what Christie (1986 in Hutchings 2000) observed in the coelomoducts of Trichobranchus glacialis Malmgren, 1866.

The biological role of the "thoracic papillae" located above the thoracic notopodia is not yet known. The shape and position of these papillae suggests that these may correspond to sensory structures. Nevertheless, trichobranchids lack dorsal and ventral parapodial cirri (Fauchald and Rouse 1997). Therefore, only a detailed histological study might reveal the actual function of these papillae.

As Garraffoni and Lana (2004) affirm, prostomial and peristomial structures in terebellomorphs have been variously interpreted by recent authors and no established terminology and literature consensus exists. Because of this and for the sake of clarity we decided to avoid as far as possible disputible terms in the description of the species and assuming those authors reinterpretation of Hutchings and Peart (2000) "peristomial lower lip" as the first segment.

The papillary projection "in posterior region of branchial lobes 1 and 2" reported by Garraffoni and Lana (2003, p. 356) was observed in our specimens in lobes 3 and 4 as well. Nevertheless, this is a fragile structure and difficult to detect and therefore its value as a diagnostic character should be used with caution. The single row of slender papillae present in the dorsal edge of branchial lamellae described by Solis-Weiss et al. (1991) for some Pacific species and Jouin-Toulmond and Hourdez (2006) for NorthAtlantic $T$. stroemii were not observed in our material. The rows of cilia in branchial lamellae reported here were also recently described by Jouin-Toulmond and Hourdez (2006) for $T$. stroemii. This might have been overlooked hitherto in other species of Terebellides and therefore be a shared character within the genus. The position of branchial stems in segments 3-4 in our specimens was previously pointed out by Hutchings and Peart (2000) for T. stroemii; this could be an artefact given that it is widely assumed that in Terebellides, branchiae are always located in segment 3 (Holthe 1986a, b; Garraffoni and Lana 2004). Finally, we agree with Solis-Weiss et al. (1991) and Garraffoni and 
Lana (2004) in regarding the fifth branchial lobe as a simple anterior projection because no sharp separation could be observed between it and branchial lobes 1 and 2 .

Acknowledgments The "Bentart" cruises were under the auspices of four MCYT and MEC (Spanish Ministry of Science and Technology and Ministry of Education and Science, respectively) Antarctic Programmes (CICYT ANT93-0996, CICYT ANT94-1161/E, MCYT REN2001-1074/ANT and MCYT CGL2004-01856). We wish to express our gratitude to all crew of the R/V "Hespérides" and the "Bentart" team, especially the team leader A. Ramos (I.E.O. Vigo, Spain) and colleagues involved in collection and sorting of polychaetes; G. San Martín and E. López (Universidad Autónoma de Madrid, Spain) and M. C. Gambi (Stazione Zoologica di Napoli, Italy). The authors also wish to thank Emma Sherlock and Alex Muir (NHM, England) for the loan of type specimens and Gudmundur Gudmundsson (Icelandic Institute and Museum of Natural History, Iceland) and Gudmundur V. Helgason (Sandgerdi Marine Centre, University of Iceland) for the loan of Icelandic Terebellides $\mathrm{cf}$. stroemii specimens from the BIOICE project. Many thanks also to R. Barreiro (RIAIDT, Universidade de Santiago de Compostela, Spain) and B. López and A. Castro (SAIN, Universidade da Coruña, Spain), who assisted with the use of the SEM and D. Romero (Universidade da Coruña, Spain) for the line drawings of syntypes. Special thanks to two anonymous referees for their helpful comments on earlier drafts of the manuscript and to David George (NHM) for checking the English.

\section{References}

Augener H (1932) Antarktische und Antiboreale Polychaeten nebst einer Hirundinee. Scientific Results of the Norwegian Antarctic expedition, 1927-28. Norske Videnskaps Akademy Oslo 9:1-86

Bartholomaeus T (1999) Structure, function and development of segmental organs in the Annelida. Hydrobiologia 402:21-37

Bremec CS, Elias R (1999) Species of Terebellides from South Atlantic waters off Argentina and Brazil (Polychaeta: Trichobranchidae). Ophelia 51:177-186

Cantone G, Di Pietro N (2001) Benthic littoral Polychaeta "Sedentaria" of Terra Nova Bay (Ross Sea, Antarctica). Ant Sci 13:3-8

Christie G (1986) Observations on the reproductive biology of Trichobranchus glacialis Malmgren, 1866 (Polychaeta: Trichobranchidae). Sarsia 71:250-263

Dales RP (1962) The polychaete stomodeum and the interrelationships of the families of Polychaeta. Proc Zool Soc Lond 139:289-328

Day JH (1967) A monograph on the Polychaeta of Southern Africa. Part 2. Sedentaria. Trustees of the British Museum (Natural History), London

Ehlers E (1897) Polychaeten. Hamburger Magalhaenische Sammelreise, Hamburg

Ehlers E (1901) Die Polychaeten des magellanischen und chilenischen Strandes. Ein faunistischer Versuch. Festschrift zur Feier des Hundertfünfzigjärigen Bestehens der Königlichen Gesellschaft der Wissenschaften zu Göttingen. Wiedmannsche Buchhandlung, Berlin

Fauchald K, Rouse G (1997) Polychaete systematics: past and present. Zool Scr 26:71-138

Fauvel P (1927) Faune de France, 16. Polychètes Sédentaires. Librairie de la Faculté des Sciences, Paris

Garraffoni ARS, Lana PC (2003) Species of Terebellides (Polychaeta, Terebellidae, Trichobranchidae) from the Brazilian coast. Iheringia Sér Zool 93:355-363

Garraffoni ARS, Lana PC (2004) Cladistic analysis of the subfamily Trichobranchinae (Polychaeta: Terebellidae). J Mar Biol Ass UK 84:973-982
Garraffoni ARS, Lana PC, Hutchings P (2005) A catalogue of the Trichobranchinae (Polychaeta: Terebellidae) of the world. Zootaxa 1065:1-27

Goodrich ES (1945) The study of nephridia and genital ducts since 1895. Q J Microsc Sci 86:113-392

Hartman O (1953) Non-pelagic polychaeta of the Swedish Antarctic expedition 1901-1903. Further Zoological Results of the Swedish Antarctic Expedition 1901-1903 4:1-83

Hartman O (1959) Catalogue of the Polychaetous Annelids of the world. Parts 1 and 2. Occ Pap Allan Hancock Found Publ 23:1628

Hartman O (1966) Polychaeta Myzostomidae and Sedentaria of Antarctica. Antarctic Res Ser 7:1-158

Hartman O (1967) Polychaetous Annelids collected by the USNS Eltanin and Staten Island cruises chiefly from Antarctic seas. Allan Hancock Monogr Mar Biol 2:1-387

Hartman O (1978) Biology of Antarctic Seas, 6. Polychaeta from the Weddell Sea quadrant, Antarctica. Antarctic Res Ser 26:125-223

Hartmann-Schröder G (1965) Zur Kenntis des Sublitorals der chilenischen Küste unter besonderer Berücksichtigung der Polychaeten uns Ostracoden. Tl. II. Die Polychaeten des Sublitorals. Mitt Hamburg Zool Mus Inst 62:59-305

Hartmann-Schröder G, Rosenfeldt P (1989) Die Polychaeten der "Polarstern"-Reise ANT III/2 in die Antarktis 1984. Teil 2: Cirratulidae bis Serpulidae. Mitt Hamburg Zool Mus Inst 86:65-106

Hartmann-Schröder G, Rosenfeldt P (1991) Die Polychaeten der "Walther Herwig"-Reise 68/1 nach Elephant Island (Antarktis) 1985. Teil 2: Acrocirridae bis Sabellidae. Mitt Zool Inst 88:73-96

Hessle C (1917) Zur Kenntnis der terebellomorphen Polychaeten. Zool Bidr Upp 5:39-258

Hilbig B (2000) Family Trichobranchidae Malmgren, 1866. In: Blake JA, Hilbig B, Scott PV (eds) Taxonomic atlas of the benthic fauna of the Santa Maria Basin and Western Santa Barbara Channel, vol. 7-The Annelida Part 4. Polychaeta: Flabelligeridae to Sternaspidae. Santa Barbara Museum of Natural History, pp 295-309

Holthe T (1986a) Polychaeta Terebellomorpha. Mar Invertebr Scand 7:1-192

Holthe T (1986b) Evolution, systematics, and distribution of the Polychaeta Terebellomorpha, with a catalogue of the taxa and a bibliography. Gunneria 55:1-236

Hutchings P (1977) Terebelliform Polychaeta of the families Ampharetidae, Terebellidae and Trichobranchidae from Australia, chiefly from Moreton Bay, Queensland. Rec Aust Mus 31:1-38

Hutchings P (2000) Family Trichobranchidae. In: Beesley PL, Ross GJB, Glasby CJ (eds) Polychaetes \& allies: the southern synthesis. Fauna of Australia, vol 4A Polychaeta, Myzostomida, Pogonophora, Echiura, Sipuncula. CSIRO Publishing, Melbourne, pp 232-235

Hutchings P, Peart R (2000) A revision of the Australian Trichobranchidae (Polychaeta). Inv Tax 14:225-272

Imajima M, Williams SJ (1985) Trichobranchidae (Polychaeta) chiefly from the Sagami and Suruga Bays, collected by R/V Tansei-Maru (Cruises KT-65 - 76). Bull Natn Sci Mus Tokyo Ser A 11:7-18

Jouin-Toulmond C, Hourdez S (2006) Morphology, ultrastructure and functional anatomy of the branchial organ of Terebellides stroemii (Polychaeta: Trichobranchidae) and remarks on the systematic position of the genus Terebellides. Cah Biol Mar 47:287-299

Kritzler H (1984) Family Trichobranchidae Malmgren, 1865. In: Uebelacker JM, Johnson PG (eds) Taxonomic guide to the Polychaetes of the northern Gulf of Mexico, vol. VII. U.S. Department of Interior, Minerals and Management Service, Metairie, Louisiana, pp 53-1-53-6

Levenstein RY (1966) Polychaetous annelids of the families Terebellidae and Trichobranchidae from the Antarctic and sub Antarctic. Biological reports of the Soviet Antarctic expedition (19551958), vol. 2. Studies of marine fauna II(X):173-189. National 
Science foundation, Washington DC (Translated from Russian original of 1964)

McIntosh WC (1885) Report on the Annelida Polychaeta collected by H.M.S. "Challenger" during then years 1873-76. Report of the Scientific Results of the Exploring Voyage of H.M.S. Challenger 1873-76 12:1-554

Monro CCA (1930) Polychaete worms. Discov Rep 2:1-222

Montiel A, Ríos C, Mutschke E, Rozbaczylo N (2004) Poliquetos de fiordos y canales adyacentes al campo de hielo patagónico sur, Chile (Annelida: Polychaeta). Cienc Tecnol Mar 27:49-67

Parapar J (2003) Oweniidae (Annelida, Polychaeta) of Icelandic waters, collected by BIOICE project, with the description of Myrioglobula islandica n. sp. Sarsia 88:274-290

Parapar J, San Martín G (1997) "Sedentary" polychaetes of the Livingston Island shelf (South Shetlands, Antarctica), with the description of a new species. Polar Biol 17:502-514

Rouse GW (2001) Terebellidae Grube, 1850. In: Rouse GW, Pleijel F (eds) Polychaetes. Oxford University Press, New York, pp 246250

Rouse GW, Fauchald K (1997) Cladistics and polychaetes. Zool Scr 26:139-204

Rouse GW, Pleijel F (2001) Polychaete anatomy. In: Rouse GW, Pleijel F (eds) Polychaetes. Oxford University Press, New York, pp 18-35

Rozbaczylo N (1985) Los Anélidos Poliquetos de Chile. Índice sinonímico y distribución geográfica de especies. Monogr Biol 3:1-284

Rozbaczylo N, Moreno R, Díaz-Díaz O, Martínez S (2006) Poliquetos bentónicos submareales de fondos blandos de la región de Aysén,
Chile: Clado Terebellida (Annelida, Polychaeta). Cienc Tecnol Mar 29:71-90

San Martín G, Parapar J (1997) "Errant" polychaetes of the Livingston Island shelf (South Shetlands, Antarctica), with the description of a new species. Polar Biol 17:285-295

San Martín G, Parapar J, García FJ, Redondo MS (2000) Quantitative analysis of soft bottoms infaunal macrobenthic polychaetes from South Shetland Islands (Antarctica). Bull Mar Sci 67:83-102

Sars M (1835) Beskrivelser og lagttagelser over nogle maerkelige eller nye I Havet ved den Bergenske Kyst levende Dyr af Polypernes, Acalephernes, Radiaternes, Annelidernes og Molluskernes classer, med en kort Oversigt over de hidtil af Forfatteren sammesteds fundne Arter og deres Fore1kommen. Thorstein Hallegers Forlag, Bergen

Sicinski J, Gillet P (2002) Biogeographical affinities of polychaetes from Îles Crozet. Ant Sci 14:353-363

Sicinski J (2004) Polychaetes of Antarctic sublittoral in the proglacial zone (King George Island, South Shetland Islands). Pol Polar Res 25:67-96

Solis-Weiss V, Fauchald K, Blankensteyn A (1991) Trichobranchidae (Polychaeta) from shallow warm water areas in the western Atlantic Ocean. Proc Biol Soc Wash 104:147-158

Williams SJ (1984) The status of Terebellides stroemi (Polychaeta: Trichobranchidae) as a cosmopolitan species, based on a worldwide morphological survey, including description of a new species. In: Hutchings PA (ed) Proceedings of the First International Polychaete Conference, Sydney, Australia, pp 118-142 